\title{
Parathyroid Hormone Resistance
}

National Cancer Institute

\section{Source}

National Cancer Institute. Parathyroid Hormone Resistance. NCI Thesaurus. Code C131298.

A finding indicating decreased tissue sensitivity to parathyroid hormone. 